Dear Author,

Please, note that changes made to the HTML content will be added to the article before publication, but are not reflected in this PDF.

Note also that this file should not be used for submitting corrections. 


\section{AUTHOR QUERY FORM}

\begin{tabular}{|c|c|c|}
\hline 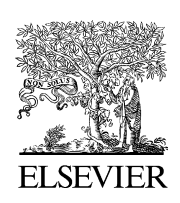 & Journal: GEOMOR & $\begin{array}{l}\text { Please e-mail or fax your responses and any corrections to: } \\
\text { Narasimhan, Karuna } \\
\text { E-mail: Corrections.ESCH@elsevier.spitech.com } \\
\text { Fax: +1 } 6196996721\end{array}$ \\
\hline
\end{tabular}

Dear Author,

Please check your proof carefully and mark all corrections at the appropriate place in the proof (e.g., by using on-screen annotation in the PDF file) or compile them in a separate list. Note: if you opt to annotate the file with software other than Adobe Reader then please also highlight the appropriate place in the PDF file. To ensure fast publication of your paper please return your corrections within 48 hours.

For correction or revision of any artwork, please consult http://www.elsevier.com/artworkinstructions.

We were unable to process your file(s) fully electronically and have proceeded by

Scanning (parts of) your article

Any queries or remarks that have arisen during the processing of your manuscript are listed below and highlighted by flags in the proof. Click on the ' $Q$ ' link to go to the location in the proof.

\begin{tabular}{|l|l|}
\hline Location in article & \multicolumn{1}{c|}{$\begin{array}{c}\text { Query / Remark: click on the Q link to go } \\
\text { Please insert your reply or correction at the corresponding line in the proof }\end{array}$} \\
\hline Q1 & Please confirm that given names and surnames have been identified correctly. \\
\hline Q2 & Please provide an update for reference "Gurnell et al., in press". \\
\hline Q3 & $\begin{array}{l}\text { Please provide an update for reference "Nardi and Rinaldi, submitted for publication". } \\
\text { corrections to make to the PDF file. }\end{array}$ \\
\hline
\end{tabular}

Thank you for your assistance. 


\section{Highlights}

Reach-scale morphological adjustments and stages of channel evolution: The case of the Trebbia River (northern Italy)

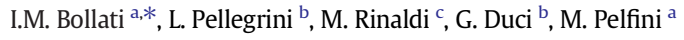

a Department of Earth Sciences, University of Milan, Via Mangiagalli, 34-20133 Milan, Italy

${ }^{\mathrm{b}}$ Department of Earth and Environmental Sciences, University of Pavia, Via Ferrata 1, 27100 Pavia, Italy

c Department of Earth Sciences, University of Florence, Via S. Marta, 3-50139 Florence, Italy

- Reconstruction of the trajectories of change in channel width and bed elevation

- Width vs. bed-level adjustments at reach-scale have been investigated.

- Tree ring data allowed us to achieve additional information on channel evolution.

- A conceptual model of channel evolution for Trebbia river has been proposed. 
Map KMZ file containing the Google map of the most important areas described in this article. 


\title{
Reach-scale morphological adjustments and stages of channel evolution: The case of the Trebbia River (northern Italy)
}

\author{
I.M. Bollati a,*, L. Pellegrini ${ }^{\text {b }}$, M. Rinaldi ${ }^{\text {c }}$, G. Duci ${ }^{\text {b }}$, M. Pelfini ${ }^{\text {a }}$ \\ a Department of Earth Sciences, University of Milan, Via Mangiagalli, 34-20133 Milan, Italy \\ b Department of Earth and Environmental Sciences, University of Pavia, Via Ferrata 1, 27100 Pavia, Italy \\ c Department of Earth Sciences, University of Florence, Via S. Marta, 3-50139 Florence, Italy
}

\section{A R T I C L E I N F O}

\section{Article history:}

Received 21 February 2014

Received in revised form 29 May 2014

Accepted 2 June 2014

Available online $\mathrm{xxxx}$

\section{Keywords:}

Channel changes

Channel adjustment

Dendrochronology

Channel evolution models

Trebbia River

\begin{abstract}
A B S T R A C T
A multitemporal series of aerial photos and cross-section topographic surveys have been used to analyze reach- 19 scale channel evolution along a segment (length of about $22 \mathrm{~km}$ ) of the lower Trebbia River (Northern Italy) with 20 the aims to investigate the relations between channel width vs. bed-level adjustments and to identify spatio- 21 temporal patterns of stages of channel evolution. Dendrochronology was used to determine the age of tree estab- 22 lishment of riparian and island forests during channel evolution.

We identified a first phase of major adjustments (1954-1992) following a series of disturbances, dominated by 24 channel narrowing and bed incision. During the final stage of narrowing, woody vegetation establishment con- 25 tributed to stabilize new floodplain or island surfaces. A period of partial morphological recovery occurred 26 from 1992 to 2010, dominated by an inversion of trend of channel width. During the phase of partial recovery, 27 a stage of widening combined with a continuation of bed incision was identified, and a last stage characterized 28 by widening and initial aggradation was observed on the central portion of the study reaches. Suitability and dif- 29 ferences of existing channel evolution models (CEMs) derived in other geographical contexts were discussed, 30 and a specific conceptual model comprising four stages of channel evolution was developed for the lower Trebbia 31 River.
\end{abstract}

(c) 2014 Elsevier B.V. All rights reserved.

\section{Introduction}

Adjustments in alluvial channel morphology have important implications in terms of ecosystem functioning and hazards associated with river dynamics. Knowledge of past trajectories of morphological change is recognized as a fundamental step for correctly interpreting current channel conditions and for predicting likely future trends (Brierley et al., 2008; Dufour and Piégay, 2009). Furthermore, understanding how a river channel has adjusted to natural events or human alterations can provide a basic knowledge for assessing river susceptibility or sensitivity (e.g., Bledsoe et al., 2012; Downs et al., 2013), and prediction of likely future river conditions is fundamental for defining morphological recovery potential and therefore to set realistic targets for river management and restoration (Brierley et al., 2008).

Morphological channel changes associated with natural events and human factors, and mutual relations between channel width and bed-

\footnotetext{
* Corresponding author. Tel.: + 39 0250315514; fax: + 390250315494.

E-mail addresses: irene.bollati@unimi.it (I.M. Bollati), luisa.pellegrini@unipv.it (L. Pellegrini), mrinaldi@dicea.unifi.it (M. Rinaldi), gabriele.duci@gmail.com (G. Duci), manuela.pelfini@unimi.it (M. Pelfini).
}

level adjustments, have been analyzed by several authors (e.g., Schumm 53 et al., 1984; Simon, 1989; Simon and Thorne, 1996; Liébault and Piégay, 54 2002; Simon and Rinaldi, 2006). Various conceptual channel evolution 55 models (CEMs) describing a sequence of stages of channel evolution 56 were initially developed for incising single-thread channels (e.g., 57 Schumm et al., 1984; Simon and Hupp, 1986). Although they have been 58 subsequently applied and verified in several areas (Simon and Thorne, 59 1996; Simon and Rinaldi, 2000, 2006), it has also been recognized that dif- 60 ferent or extended sequences of channel evolution can be observed, de- 61 pending on various factors (e.g., Elliott et al., 1999; Thorne, 1999; 62 Hawley et al., 2012; Cluer and Thorne, 2013).

An increasing number of studies have analyzed channel adjustments 64 of Italian rivers recently (e.g., Rinaldi, 2003; Surian and Rinaldi, 2003; 65 Surian et al., 2009; Ziliani and Surian, 2012). Many of these studies 66 have conducted multitemporal analyses of aerial photos, showing 67 detailed trajectories of channel width and identifying progressive adjust- 68 ments (e.g., Surian et al., 2009). After two historical phases of predomi- 69 nant channel narrowing and bed incision, a more recent inversion of 70 trend (after the 1990s) consisting of widening and aggradation has 71 been described for some rivers (Surian and Rinaldi, 2004; Rinaldi et al., 72 2009; Surian et al., 2009; Ziliani and Surian, 2012). However, this recent 73 phase of partial recovery and the processes leading to the inversion of 74 trend have not been completely clarified. This is partly related to the 75 
fact that only a few studies included extensive data on bed elevation changes (Rinaldi and Simon, 1998; Surian and Cisotto, 2007; Ziliani and Surian, 2012), preventing investigation of the relations between channel width and bed-level adjustments in more detail. Classification schemes of channel adjustments have been developed (e.g., Surian and Rinaldi, 2003), and some differences with existing channel evolution models have already been discussed (e.g., Rinaldi and Simon, 1998; Rinaldi, 2003). For example, CEMs were originally developed and mostly applied to incised single thread channels with predominantly cohesive banks, while many studies on Italian rivers concern braided or wandering, coarse-grained conditions.

The role of vegetation on the development of depositional surfaces during morphological recovery following disturbances has also been recognized as fundamental (e.g., Hupp and Simon, 1991; Hupp, 1992); however, few studies have focused on these aspects related to the evolution of Italian rivers (e.g., Hupp and Rinaldi, 2007; Comiti et al., 2011). A particular feature characterizing the fluvial environment is the strict and reciprocal relationship that exists between the active geomorphic processes responsible for the variation of fluvial patterns and the biotic components of the landscape (Corenblit et al., 2014). In this sense, the riparian vegetation and investigations on its evolution may provide important information on river evolution (e.g., Hupp and Rinaldi, 2007). Moreover, detailed evolution models have been recently proposed, as for example the fluvial biogeomorphic succession (FBS) model of Corenblit et al. (2007) in which different stages of riparian vegetation succession are linked to fluvial landform adjustments through time. The characteristics of riparian vegetation may be considered indicative of the current stability of landforms, and for this reason the acquisition of data regarding the age of stabilization of fluvial surfaces (i.e., floodplain and islands) has been performed through a dendrochronological sampling to provide additional information on channel adjustments.

Braided rivers were common in Alpine regions of Italy during the last century, but they have undergone dramatic changes because of human activities. Few braided rivers still exist in northeastern Italy (for example the Tagliamento River) as well as in southeastern France, and there is a need to promote preservation of these morphologies because of the biodiversity sustained by the dynamic mosaic of terrestrial and aquatic habitats (Gurnell et al., 2009; Piégay et al., 2009; Belletti et al., 2013). Apenninic braided rivers are even more uncommon and have received less attention; therefore, studies that aim to understand past evolution and likely future trends of such morphologies are important.

The previous overview on Italian rivers provides a general background of scientific gaps and motivations associated with the present study on the Trebbia River. The Trebbia catchment is located on the northern Apennines and the river has an originally braided morphology (before recent adjustments) and still maintains a tendency toward braiding along some portion of its course (e.g., Bollati et al., 2012). Previous studies on the alluvial portion of the Trebbia River allowed identification of the overall trajectories of morphological changes and the determination of their relation to the main human disturbances over the last 150-200 years (Rinaldi et al., 2005a; Pellegrini et al., 2008). This study permits the documentation of the evolution of an originally braided river, combining previous knowledge with the acquisition of new data that allowed for the investigation of channel width vs. bedlevel adjustments in more detail.

Specific aims of this paper are (i) to investigate channel adjustment at different spatial scales, i.e., at segment vs. reach-scale, to identify whether a spatiotemporal sequence of stages of evolution can be recognized; (ii) to clarify interactions of channel width vs. bed-level changes during the various stages of channel evolution, including an assessment of the age of vegetation establishment during morphological recovery; and (iii) to make a synthetic review of existing CEMs derived in other geographical contexts, based on which we discuss suitability and differences and/or to develop a specific conceptual model of channel evolution.

\section{Study area}

\subsection{General setting}

The Trebbia catchment is located in the northern Apennines (Emilia 144 Romagna, northern Italy) and covers an area of about $1070 \mathrm{~km}^{2}$ (Fig. 1). 145 The physiography of the catchment consists of largely mountainous and 146 hilly areas ( $85 \%$ of the total), with a basin relief of about $1406 \mathrm{~m}$; geol- 147 ogy is characterized by sedimentary series, mainly marls and sand- 148 stones, and outcroppings of ophiolitic rocks in some areas of the 149 catchment. The climate is characterized by a cold winter and a dry sum- 150 mer season; mean annual rainfall is $1440 \mathrm{~mm} / \mathrm{y}$, with most of the pre- 151 cipitation occurring during autumn and spring, with October and April 152 being the rainiest months.

153

The Trebbia is one of the main tributaries of the Po River, with a total 154 length of about $120 \mathrm{~km}$; mean annual discharge along the medium por- 155 tion of the river is estimated to be about $35 \mathrm{~m}^{3} / \mathrm{s}$ (gauging station of San 156 Salvatore, drainage area of $631 \mathrm{~km}^{2}$; Fig. 1).

The spatial pattern of channel morphology is strongly controlled by 158 the physiographic conditions of the valley, with frequent confined me- 159 anders in the upper reach, followed by prevailing partly confined 160 reaches crossing the hilly areas, and then unconfined reaches with a 161 tendency toward braiding along a wide alluvial fan included in the Po 162 River plain. In this study we focussed on the latter unconfined river sec- 163 tion, having a length of $22.125 \mathrm{~km}$ (Fig. 1A). According to the segmenta- 164 tion procedure defined by Rinaldi et al. (2013) and Gurnell et al. (in 165 press), the investigated section was defined as a river segment that is 166 a macroreach with similar conditions in terms of valley setting. The seg- 167 ment was then divided into seven reaches (Fig. 1B) with relatively ho- 168 mogeneous morphological characteristics and same channel typology 169 (Table 1). The final reach (i.e., about the last $1000 \mathrm{~m}$ before the conflu- 170 ence with the Po River) has been excluded from the analysis because of 171 significant artificial control on channel morphology (artificial levees) 172 and because of some gaps in map and aerial photo coverage. Current 173 channel morphology of the analyzed river segment is predominantly 174 wandering, but with some narrower reaches ( 1 and 6) where channel 175 pattern can be better described as sinuous with alternate bars 176 (Rinaldi, 2003; Rinaldi et al., 2013) and other wider reaches with a 177 marked tendency toward braiding (3 and 4). Channel slope ranges 178 from about 0.2 to $0.4 \%$; median diameter of bed sediments is in the 179 range of 33 to $80 \mathrm{~mm}$ (Rinaldi et al., 2005a; Pellegrini et al., 2008; 180 Surian et al., 2009).

\subsection{Human disturbances and impacts}

Similar to other Italian rivers (Surian and Rinaldi, 2003; Surian et al., 183 2009), the Trebbia River and its catchment have been affected by the 184 following human disturbances during the last centuries (Rinaldi et al., 185 2005b; Pellegrini et al., 2008): (i) construction of levees and other pro- 186 tection structures (nineteenth to twentieth centuries); (ii) reforestation 187 in the drainage basin (nineteenth to twentieth centuries); (iii) con- 188 struction of two dams in the upstream portions of some tributaries 189 and three main weirs along the main channel (1950s to 1970s) 190 (Fig. 1); (iv) intense sediment mining, started after World War II and 191 with the maximum intensity between the 1960s and 1980s (Surian 192 et al., 2009).

Land use change in the Trebbia catchment over the last 130 years 194 has been documented by Duci (2011) using four different data sets; ag- 195 gregation of data into five classes of land use allowed a comparison be- 196 tween such data sets (Table 2). The main result of this investigation is 197 the progressive increase of forest cover, from $22 \%$ to $51 \%$ of the catch- 198 ment area, respectively, in 1885 and 2006. The dams are located in the 199 upper catchment but may have significantly affected the flow and sed- 200 iment regime. Sediment mining has probably caused the most impor- 201 tant alterations on channel morphology. Although quantitative data 202 on extracted sediment volumes are lacking, segment-scale sediment 203 

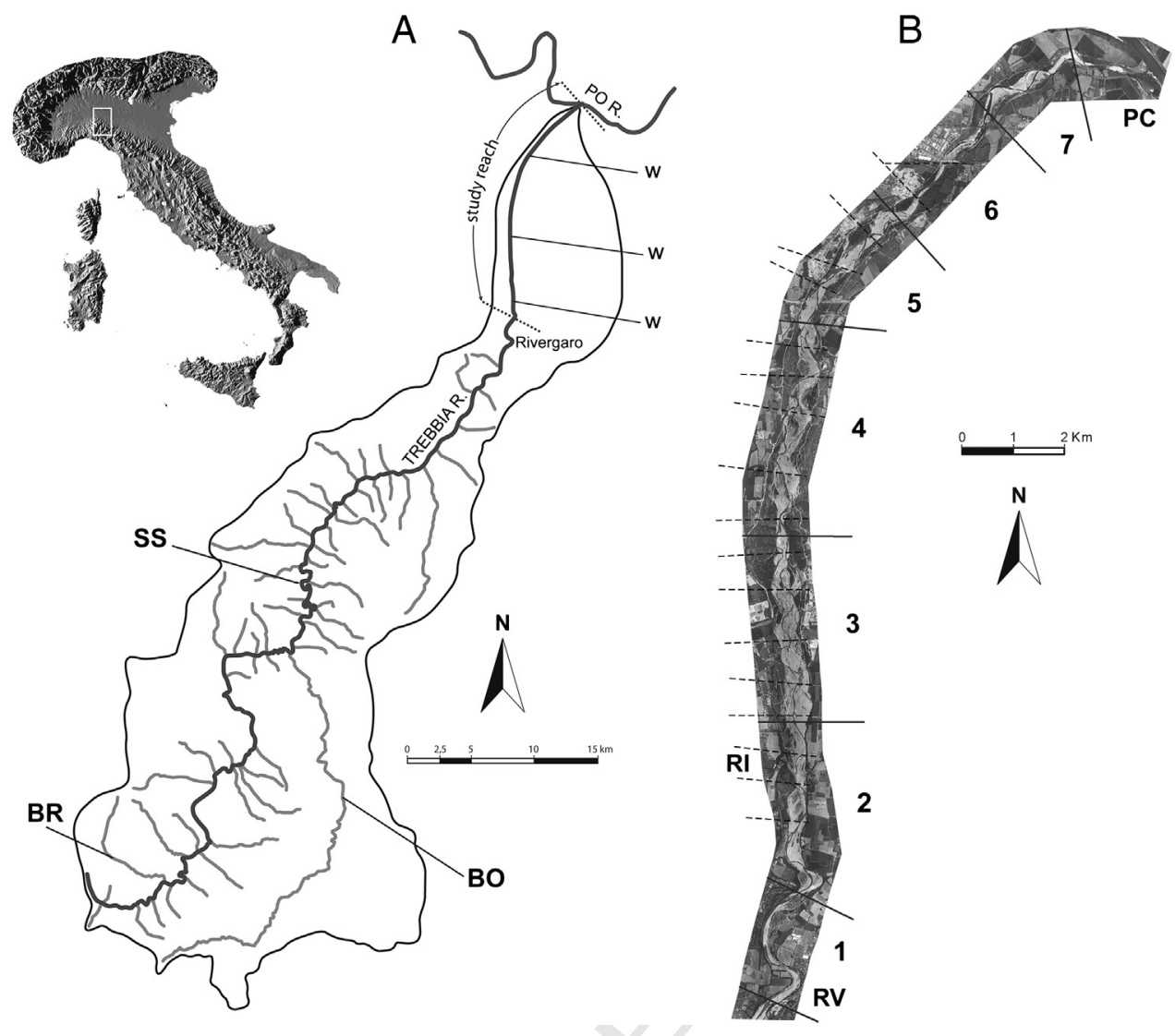

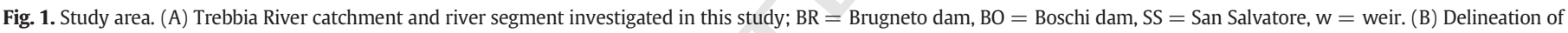
homogeneous reaches from aerial photos of 2010 (continuous line), dashed line $=$ cross section, PC $=$ Piacenza, RI $=$ Rivalta, RV $=$ Rivergaro.

exploitation has been very intensive during the period from the $1960 \mathrm{~s}$ to the 1980 s as a result of industrialization and urbanization of the area, which has been drastically limited by national legislation since the beginning of the 1990s.

\section{Materials and methods}

A multitemporal GIS analysis of planform changes was conducted, starting from historical maps dated 1885 and including a time sequence of 11 aerial photographs from 1954 to 2010 at various scales (Table 3). Older maps (1815, scale $1: 100,000)$ were also used to qualitatively assess the channel morphology of that period but were not included in the quantitative analysis of changes because of the potential for significant error. The GIS analysis consisted of orthorectification and georeferencing of each image, digitalization of channel margins, and measurement of width of the channel and islands. Orthorectification was performed by using ERDAS Leica Geosystem 8.7. The maps and the aerial photographs were coregistered using maps at a 1:5000 scale as a base layer; for each aerial photo, a series of ground-control points were used, and root mean square errors (RMSE) deriving from orthorectification were estimated to be lower than the pixel size of the images. After delimiting and digitizing channel margins, a centerline 223 of each year was automatically derived in GIS from the delimitation of 224 the channel margins, and a series of cross sections orthogonal to the 225 centerline were generated for each year. Then, channel width was mea- 226 sured for each of these cross sections as the sum of submerged channels 227 and unvegetated or sparsely vegetated depositional bars. A spatial inter- 228 val of $25 \mathrm{~m}$ between cross sections of measurement was used, which is 229 relatively short spacing, on the order of one-tenth of the average chan- 230 nel width of 2010 .

Limitations and errors related to georectification and digitizing of 232 channel morphological features have been discussed by various authors 233 (e.g., Gurnell, 1997; Winterbottom, 2000; Hughes et al., 2006). Accord- 234 ing to previous similar analyses using the same methodologies (e.g., 235 Downward et al., 1994; Winterbottom, 2000; Liébault and Piégay, 236 2001; Rinaldi et al., 2009; Surian et al., 2009; Ziliani and Surian, 2012), 237 a maximum error of 20 and $6 \mathrm{~m}$, respectively, was estimated for our 238 measurements on the historical map and aerial photographs.

Bed-level changes were investigated by a time series of four topo- 240 graphic surveys of cross sections (Fig. 1; Table 3). Previous studies 241 (Rinaldi et al., 2005a; Pellegrini et al., 2008) have made use of the first 242 available surveys (1974, 1992, and 2003) to assess the overall changes 243

Table 1

Main characteristics of the morphological reaches.

\begin{tabular}{|c|c|c|c|}
\hline Reach & Length $(\mathrm{m})$ & Typology & Distinctive morphological characteristics \\
\hline 1 & 2850 & Sinuous with alternate bars & Relatively narrow, prevailing single-thread, alternate side bars \\
\hline 2 & 3500 & Wandering & Increasing width, local braiding \\
\hline 3 & 3625 & Wandering & Increasing width, braiding and islands \\
\hline 4 & 4225 & Wandering & Decreasing braiding \\
\hline 5 & 3050 & Wandering & Decreasing width, local braiding \\
\hline 6 & 2700 & Sinuous with alternate bars & Relatively narrow, prevailing single-thread, alternate side bars, local braiding \\
\hline 7 & 2175 & Wandering & Increasing width, highly sinuous baseflow \\
\hline
\end{tabular}


t2.1 Table 2

t2.2 Land use changes in the Trebbia catchment over the last 130 years (from Duci, 2011). Land t2.3 use data derive from Regione Emilia Romagna (1885 and 1976) and from Corine land t2.4 cover (1994 and 2003).

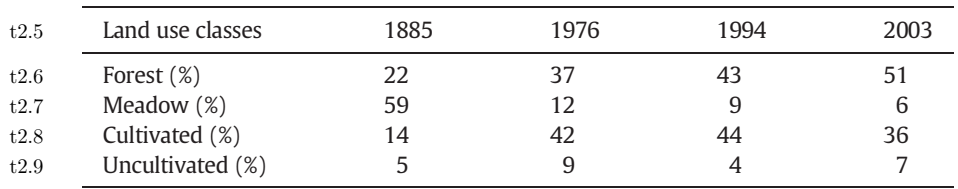

of longitudinal profiles. In this study, a new survey was done in 2009, consisting of a series of 18 cross sections overlapping the position of the previous cross sections of 2003. The survey was conducted using GPS equipment, consisting of two Topcon Hyper Pro antennas and a Topcon FC100 receiver; estimated planimetric and altimetric maximum error was about 2.5 and $4 \mathrm{~cm}$, respectively.

For each cross section of the available surveys, the mean bed elevation was obtained as the average elevation of all the points of the channel bed starting from the bank toe (banks were excluded from this calculation). A weighted average elevation taking into account the distance between each pair of points was used, then the longitudinal profile of mean bed elevation was obtained for each year. In order to obtain a mean change of bed elevation along the longitudinal profile for each pair of years, the difference of the areas subtended by the longitudinal profiles of the two years was calculated for a given reach length.

A series of field surveys were performed to verify consistency of field evidence with the results of bed-level changes assessed by the longitudinal profiles and to gain additional information on present trends of adjustments. Interpretation of bed-level adjustments was supported by the application of specific field sheets (Rinaldi, 2008), and by using a series of evidence, including differences in elevation between homologous geomorphic surfaces (Rinaldi, 2003; Liébault et al., 2013).

Field work also included dendrochronological sample collection and analysis. Dendrochronology and botanical evidence have been widely used to analyze interactions of fluvial processes and hydrogeomorphic conditions in different morphogenetic contexts (e.g., Sigafoos, 1964; Hupp and Osterkamp, 1996; Hupp and Bornette, 2003; Pelfini et al., 2006; Garavaglia et al., 2010) and to date occurrence and rates of erosional or depositional processes supporting interpretation of the stage of adjustment in CEMs (Hupp and Simon, 1991; Hupp, 1992; Hupp and Rinaldi, 2007).

A more accurate reconstruction of channel changes was obtained by using a tree ring analysis with the aim of determining the age of tree establishment and therefore to date fluvial surfaces colonized by arboreal vegetation. This analysis can provide a field verification and detail on the determination of the period for vegetation establishment and colonization of in-channel and riparian surfaces in the context of channel evolution. Two dendrochronological surveys (2009 and 2010) were conducted, during which 92 Populus nigra L. distributed on eight sites along both channel banks and on islands were sampled for dating. The eight sampling sites are located along reaches 2 and 3 and were selected as representative of areas where morphological changes observed from aerial photographs were evident (Fig. 2). According to Liébault and Piégay (2001), the age of trees of the species that belong to the first stage in the ecological succession of riparian forests (e.g., P. nigra L.) is an indicator of the date at which the geomorphic surfaces supporting these plants were formed. Corenblit et al. (2014) focused their attention 290 on this species and in particular on its biogeomorphological life cycle 291 (BLC), identifying four different stages of interactions (i.e., geomorpho- 292 logical, pioneer, biogeomorphological, and ecological) with the physical 293 landscape processes, according to the tree age.

294

The oldest trees colonizing the investigated geomorphic surface 295 were selected for tree ring analysis. Two cores were extracted from 296 each tree by using an increment borer at the standard trunk height of 297 $1.30 \mathrm{~m}$ (BH: breast height). For the dendrochronological investigations, 298 tree-ring width was measured (accuracy of $0.01 \mathrm{~mm}$ ) using the LINTAB 299 and TSAP systems (Rinn, 1996), and core image analysis was performed 300 by WinDENDRO software (Regent Instruments Inc., 2001). In order to 301 reduce dating errors (Gutsell and Johnson, 2002; Koch, 2009), cross- 302 dating of the dendrochronological series has been statistically processed 303 by the COFECHA software (Holmes et al., 1986) and visually by the 304 TSAP. The growth trend has been removed by indexing tree ring growth 305 curves using Arstan (Cook, 1985) to improve observations on abrupt 306 growth changes.

Given that the sampling height was $1.30 \mathrm{~m}$, the colonization time 308 gap (CTG) (Pierson, 2007) was considered, corresponding to the sum 309 of the germination lag time (GLT, i.e., the time interval between stabili- 310 zation of the new landform surface and germination of the sampled 311 tree) and the growth time (BHGT, i.e., the interval between seedling 312 germination and growth to sampling height).

Populus sp., and in particular P. nigra L., is generally considered among 314 the pioneer species, taking a short time to germinate on bars and new 315 floodplain surfaces (Everitt, 1968; Gottesfeld and Johnson-Gottesfeld, 316 1990; Hupp and Simon, 1991; Astrade and Bégin, 1997; Scott et al., 317 1997; Liébault and Piégay, 2001; Hupp and Rinaldi, 2007). As indicated 318 by Corenblit et al. (2014) and according to the definition by Jones et al. 319 (1994), P. nigra L. may be defined as an engineer species that exerts a 320 strong control over ecosystem function by creating or significantly mod- 321 ifying the habitat. Gutsell and Johnson (2002), working on Populus 322 tremuloides, indicated this species to be early-successional (i.e., pioneer) 323 characterized by high growth rates between the root collar and the first 324 few meters, and calculated an average age correction of $+4 / 5$ years in 325 boreal forest (assuming GLT $=0$ ). In our study, the definition of CGT pre- 326 sents some uncertainty as specific information for P. nigra L. in the partic- 327 ular morphoclimatic context of the study area was not available in 328 literature, and we defined a range rather than a fixed value. We assumed 329 that most of the sampled pioneer trees germinated during the first grow- 330 ing season after a major flow event (GLT ranging from 0 to 1 ), and a 331 BHGT of 2-3 years, resulting in a CGT ranging from 2 (MiCA, minimum 332 corrected age) to 4 years (MaCA, maximum corrected age).

333

\section{Results}

A first step of analysis consisted of integrating the existing knowl- 335 edge with the addition of the most recent data on channel width 336 (from aerial photos of 2010) and bed elevation (from cross sections of 337 2009). Channel width and bed elevation changes were aggregated at 338 segment scale in order to visualize the overall changes that occurred 339 along the entire study portion of the river. Although an exhaustive dis- 340 cussion of the causes of the various phases of adjustments is beyond the 341 scope of this paper, Fig. 3 summarizes channel adjustments and relevant 342 human factors influencing channel morphology (Pellegrini et al., 2008). 343 The two largest flood events that occurred in the period (1953 and 344

Table 3

Summary of data sources used for the analysis of channel adjustments. Type of aerial photos: C: colored; B/W: black-white.

$\begin{array}{ll}\text { Historical maps (scale) } & 1815(1: 100,000), 1885(1: 25,000) \\ \text { Aerial photos (scale) } & 1954(\mathrm{~B} / \mathrm{W}-1: 35,000), 1976(\mathrm{C}-1: 13,000), 1980(\mathrm{~B} / \mathrm{W}-1: 7,500), 1985(\mathrm{~B} / \mathrm{W}-1: 35,000), 1990(\mathrm{~B} / \mathrm{W}-1: 34,000), 1996 \\ & (\mathrm{~B} / \mathrm{W}-1: 40,000), 2000(\mathrm{C}-1: 40,000), 2002(\mathrm{C}-1: 30,000), 2003(\mathrm{~B} / \mathrm{W}-1: 5,000), 2006(\mathrm{C}-1: 12,000), 2010(\mathrm{C}-1: 8,000) \\ & 1974(9), 1992(14), 2003(18), 2009(18) \\ \text { Topographic surveys (number of cross-sections) } & 2008,2009,2010 \\ \text { Field surveys } & 2009,2010 \\ \text { Dendrochronological data } & \end{array}$



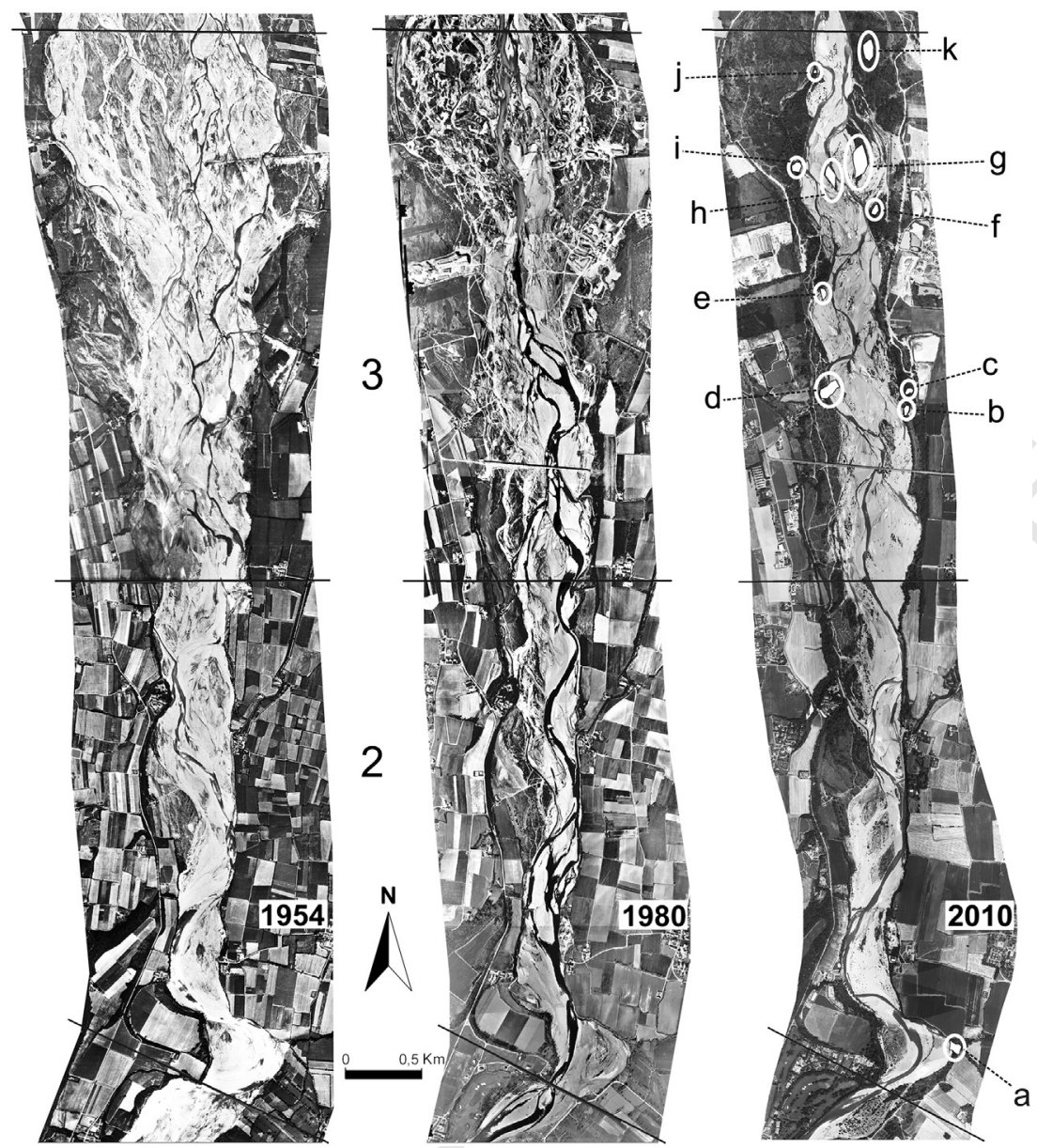

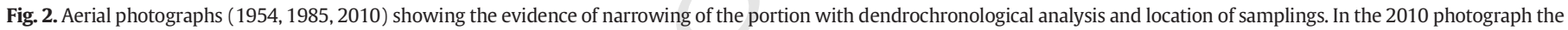
11 dendrochronological sampling areas are indicated, by lowercase letters, inside the white circles.

2000, with estimated peak discharge at San Salvatore of $3430 \mathrm{~m}^{3} / \mathrm{s}$ and $2475 \mathrm{~m}^{3} / \mathrm{s}$, respectively) are also indicated in Fig. 3. Additional information on magnitude and sequence of floods during the period of investigation was not available because of the lack of a sufficiently long time series of maximum annual peak discharge within the catchment. The three phases $(1,2$, and 3 ) indicated in Fig. 3 are those described in

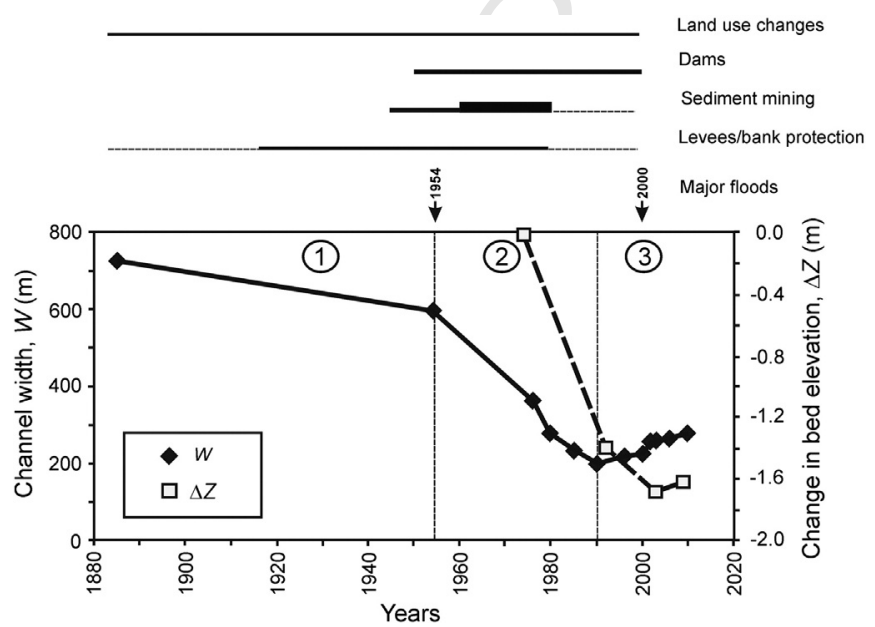

Fig. 3. Trends of width and bed-level adjustments at the segment scale with human impacts and main flood events. Human disturbances: horizontal bars indicate temporal interval and relative intensity of the different impacts. Numbers 1,2, and 3 refer to the phases of channel evolution identified in previous studies (Pellegrini et al., 2008; Surian et al., 2009). previous studies on the Trebbia River (Rinaldi et al., 2005a; Pellegrini 351 et al., 2008), as well as on many other Italian rivers (Rinaldi et al., 352 2009; Surian et al., 2009; Ziliani and Surian, 2012). Specifically, phase 353 1 refers to a first period of narrowing, mainly attributed to land use 354 changes at the catchment scale, to a partial reduction of lateral mobility 355 by bank protection and artificial levees, and eventually to a reduction of 356 sediment delivery related to the end of the Little Ice Age. Even with the 357 relatively high error in the measurement of channel width from histor- 358 ical maps, the average change from 1885 to 1954 was about $130 \mathrm{~m}, 359$ therefore well above the margin of error. Phase 2 refers to the main 360 phase of narrowing and incision starting from the 1950s and mainly as- 361 sociated with intensive sediment exploitation (Pellegrini et al., 2008). 362 Phase 3 concerns the recent period (about the last 15 years) of inversion 363 in the channel-width trend related to a partial recovery of channel 364 morphology (i.e., an increase in channel width and a tendency toward 365 braiding) mainly as a consequence of a drastic reduction in sediment 366 removal.

The second part of the analysis focused on the period of major ad- 368 justments after the 1950s and the following period of partial recovery 369 (i.e., phases previously indicated as 2 and 3). In this second part, we an- 370 alyzed change at the reach scale in order to determine in more detail 371 whether the trends were similar to those observed at the segment 372 scale, or if there were differences between reaches reflecting some spa- 373 tiotemporal pattern of evolution.

Channel width measurements were aggregated for each of the seven 375 morphological reaches previously defined; bed profiles were also inte- 376 grated from different years along the same reaches. Results of this anal- 377 ysis are shown in Fig. 4 (bed elevation data were available for reaches 2378 to 6 only). The analysis of the trajectories of change for the different 379 

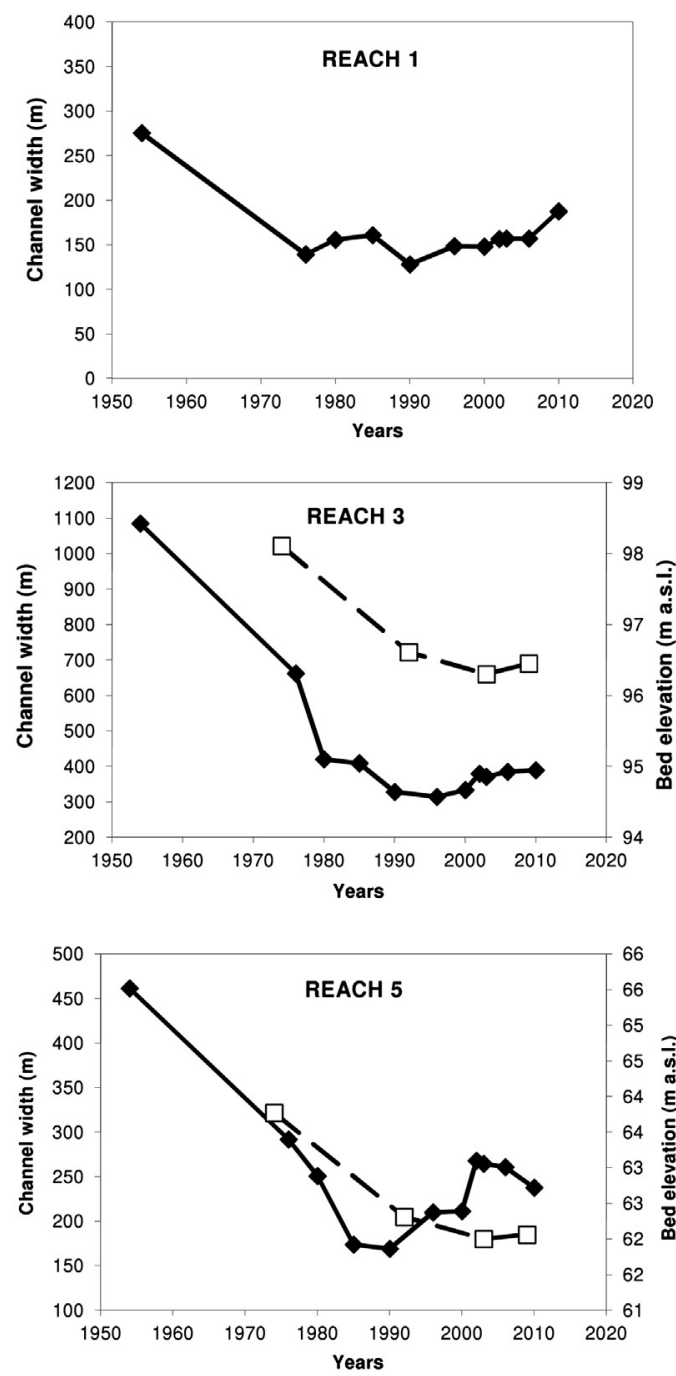
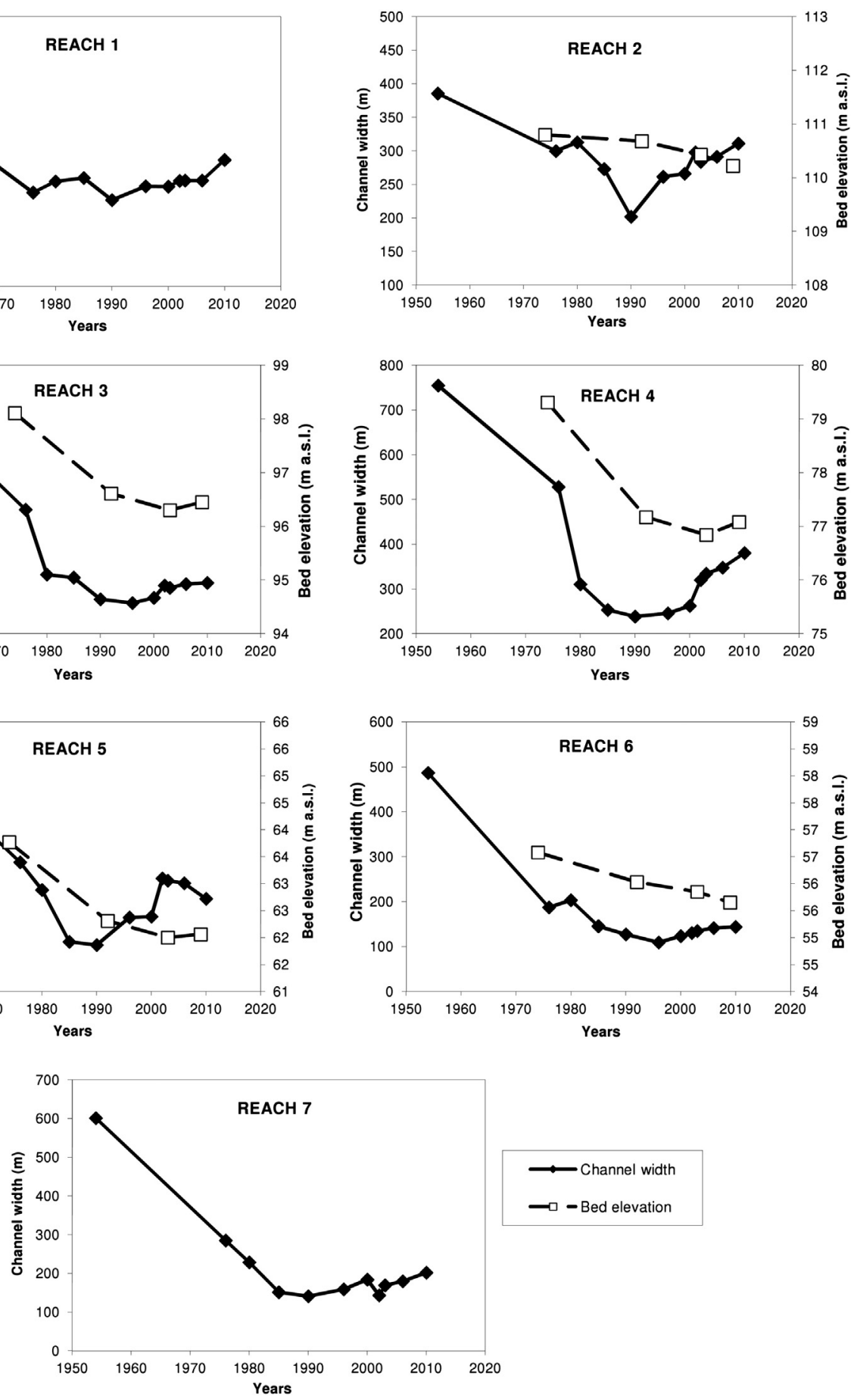

Fig. 4. Trends of adjustments at reach-scale over the last 60 years.

reaches shows, as expected, a more variable range of situations accounting for some local conditions but still sharing common general characteristics. In regard to the trajectories of channel width (Fig. 4), we identified the time intervals of the two main phases (major adjustment and partial recovery phases) and classified the types of change (Table 4).

The phase of major adjustment was dominated by channel narrowing, with some short periods of limited widening (reaches 1,2 , and 6 , for an interval time of $<10$ years). The end of this phase ranges from 1990 (five out of seven cases) to 1996 (the remaining two cases). The partial recovery phase was characterized by dominant widening but often alternating with shorter periods of limited narrowing.
The amount of change during the partial recovery phase was significant- 392 ly lower than that of the major adjustment, ranging from about $10 \% 393$ (reaches 3 and 6) to 60\% (reach 2), also as a consequence of the shorter 394 time interval.

The low number of available data points did not allow for the recon- 396 struction of the trajectories of bed-level change with the same detail as 397 channel width. A synthesis of width and bed-level adjustments during 398 the investigated period 1954-2010 for all the reaches is reported in 399 Table 5. From this summary, no recognizable spatiotemporal patterns 400 of change are evident (e.g., upstream or downstream migration of 401 some process through time). Rather, the central portion (reaches 3, 4, 402 5) exhibits a quite similar pattern of changes, particularly in terms of 403 


\section{t4.1 Table 4}

t4.2 Summary of channel width adjustments. $\Delta \mathrm{W}$ : change in channel width; $\mathrm{N}$ and $\mathrm{n}$ : t4.3 narrowing; $W$ and w: widening; I and i: incision; $A$ and a: aggradation (capital letter for t4.4 major phases, i.e. $>10$ years long)

\begin{tabular}{|c|c|c|c|c|c|c|}
\hline \multirow[t]{2}{*}{ Reach } & \multicolumn{3}{|c|}{ Period of major adjustment } & \multicolumn{3}{|c|}{ Period of secondary adjustments } \\
\hline & Time & $\Delta \mathrm{W}(\mathrm{m})$ & Adjustments & Time & $\Delta \mathrm{W}(\mathrm{m})$ & Adjustments \\
\hline 1 & 1954-1990 & -147.4 & $\mathrm{~N}-\mathrm{w}-\mathrm{n}$ & 1990-2010 & 59.3 & W \\
\hline 2 & 1954-1990 & -183.8 & $\mathrm{~N}-\mathrm{w}-\mathrm{N}$ & $1990-2010$ & 109.2 & W-n-w \\
\hline 3 & 1954-1996 & -770.5 & $\mathrm{~N}$ & 1996-2010 & 74.7 & W-n-w \\
\hline 4 & 1954-1990 & -516.6 & $\mathrm{~N}$ & 1990-2010 & 142.2 & W \\
\hline 5 & 1954-1990 & -292.0 & $\mathrm{~N}$ & $1990-2010$ & 68.8 & W-n \\
\hline 6 & 1954-1996 & -377.6 & $\mathrm{~N}-\mathrm{w}-\mathrm{N}$ & 1996-2010 & 34.6 & W \\
\hline 7 & 1954-1990 & -459.6 & $\mathrm{~N}$ & 1990-2010 & 60.4 & W-n-w \\
\hline
\end{tabular}

bed elevation with bed aggradation following incision, whereas bed incision occurred for the entire period along reaches 2 and 6 .

Bed incision is clearly the most common type of adjustment, but with the important consideration that in three out of five cases bedlevel lowering did not continue during the last time interval (2003-2009) and was replaced by a slight aggradation or stability. Concerning the relations between channel width and bed elevation changes, a first qualitative result deriving from Table 5 is that the decreasing trends in bed elevation are prolonged for some years after narrowing converted to predominant widening. Therefore, bed aggradation or stability and channel widening do not entirely occur during the same interval of time, but there is a period when incision and widening occur together.

We assessed more quantitatively the relations between channel width vs. bed-level adjustments, and we investigated the existence of spatiotemporal patterns. We chose three periods (1974-1992, 1992-2003, 2003-2009) dictated by the availability of bed elevation data. For these three periods we selected the channel width data closest to the years with topographic surveys $(1974,1992,2003,2009)$. A maximum difference of 2 years exists between bed elevation and channel width data. The three selected periods are also meaningful in terms of trajectories of change, given that the first period (1974-1992) covers the second half of the major adjustments, and the following two intervals (1992-2003 and 2003-2009) are associated with the recent phase of partial recovery. Changes in channel width vs. bed elevation for the same time interval are plotted in Fig. 5, from which the following considerations can be drawn: (i) the period 1974-1992 is dominated by the associated incision-narrowing and by the high amounts of both processes; (ii) during the second period (1992-2003), a very clear association of widening and incision is apparent; and (iii) the final period (2003-2009) is characterized by the highest variability, but with an important shift toward aggradation (three out of five points).

Results of the dendrochronological analysis are summarized in Fig. 6, where the number of trees germinating in the time interval 1963-2000 are reported for the two reaches where samples were collected (Fig. 2). From the analysis of aerial photographs, these samples are localized on geomorphic surfaces that originated during channel narrowing in the interval 1980-1990. Determination of the year of tree germination allowed identification of the year of arboreal vegetation establishment on riparian and island surfaces in more detail and, therefore, the timing of stabilization of new floodplains and islands during the narrowing phase.

Correlation results among the annual ring width curves of the trees in the eight sampling areas are sufficiently good, showing an average COFECHA correlation index of 0.4966 , with the highest values (0.5460.747 ) associated with the 11 sampling areas located along the left channel bank ((d), (e), (i), and (j) in Fig. 2). The oldest sampled surface (the most southern, (a) in Fig. 2) is located along the outer bank of a meandering bend along reach 2 . In this location, most of the trees populating the surface germinated between the late 1970s and the early 1990s with a peak in 1977 (MaCA)-1979 (MiCA) (see details in Fig. 6). Other sites, located along reach 3 ((b)-(k) in Fig. 2) were all completely established in

\section{Table 5}

Summary of phases of channel width and bed-level adjustments. $\mathrm{N}$ and $\mathrm{n}$ : narrowing; $\mathrm{W}$ and w: widening; I and i: incision; A and a: aggradation (capital letter for major phases, i.e. $>10$ years long).

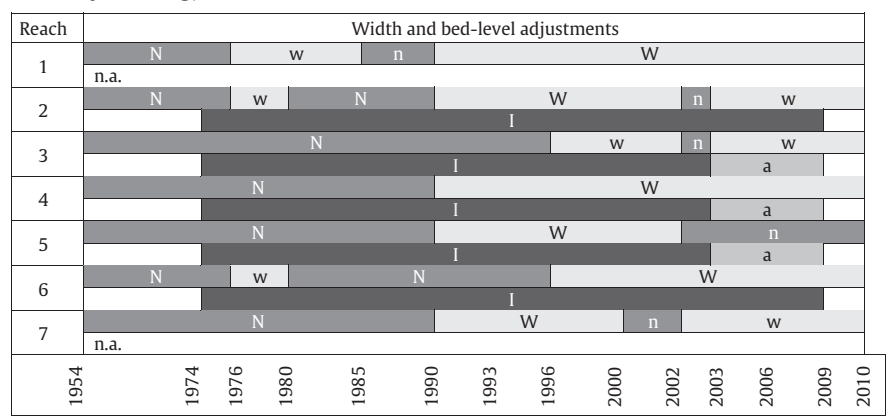

the first half of the 1990s. The peak of germination was reached in 1985456 (MaCA)-1987 (MiCA), suggesting a younger age for the corresponding 457 surfaces. In detail, the trees on islands germinated between 1983 and 458 1992 (MiCAs), while the investigated surfaces located on the left bank 459 were colonized mainly in the period 1984-1995 (MiCAs) and 1984- 460 1991 (MiCAs) on the right bank. In summary, this data provides addition- 461 al field evidence that the colonization of arboreal vegetation along the in- 462 vestigated reaches mainly occurred during (1977-1979) (reach 2) or 463 after (1984-1986) (reach 3) the period of major channel narrowing 464 (phase 2). Arboreal vegetation initially established on newly formed sur- 465 faces (floodplain and islands) during the final phase of incision and 466 narrowing.

\section{Discussion}

Results of the analysis of channel changes along a river length of 469 about $22 \mathrm{~km}$ and over a period of about 60 years show evidence of a 470 temporal sequence of stages characterized by different combinations 471 of width and bed-level adjustments. The following discussion is 472 organized as follows: (i) the discussion of the results of this study is pre- 473 ceded by a synthetic review of existing CEMs developed in other geo- 474 graphical contexts, and on their applicability to Italian river systems 475 based on previous studies; and (ii) results for the Trebbia River are 476 discussed and set within a conceptual framework of channel evolution, 477 reconsidering differences with existing CEMs previously identified.

\subsection{Existing knowledge on CEMs and on their applicability to Italian rivers 479}

Research conducted in various areas of the United States has shown a 480 sequence of stages of channel evolution for river systems disturbed by 481 channelization, base level lowering, or alterations to the flow and/or sed- 482 iment regimes (Schumm et al., 1984; Simon and Hupp, 1986; Simon, 483 1989). This typical succession of stages has led to the development of a 484 series of channel evolution models (CEMs) based on the concept of 485 location-for-time substitution and shifts in dominant adjustment pro- 486 cesses. These models describe a phase of initial bed incision, followed 487 by bank instability and widening, and by a subsequent stage of down- 488 stream aggradation as degradation migrates upstream. Bed incision 489 (degradation) is typically the first primary adjustment following the 490 human disturbance, followed by channel widening because banks ex- 491 ceed critical height (depending on their composition) for bank failure. 492 Then, downstream bed aggradation begins as a result of bank sediment 493 delivery from upstream, and a new floodplain is progressively rebuilt 494 during the recovery phase leading to the progressive establishment of 495 an endpoint 'quasi-equilibrium' morphology.

496

The CEMs were initially developed for incising, single-thread chan- 497 nels and, although they have been subsequently applied and verified 498 in several areas (Simon and Thorne, 1996; Simon and Rinaldi, 2000, 499

\section{.} . 


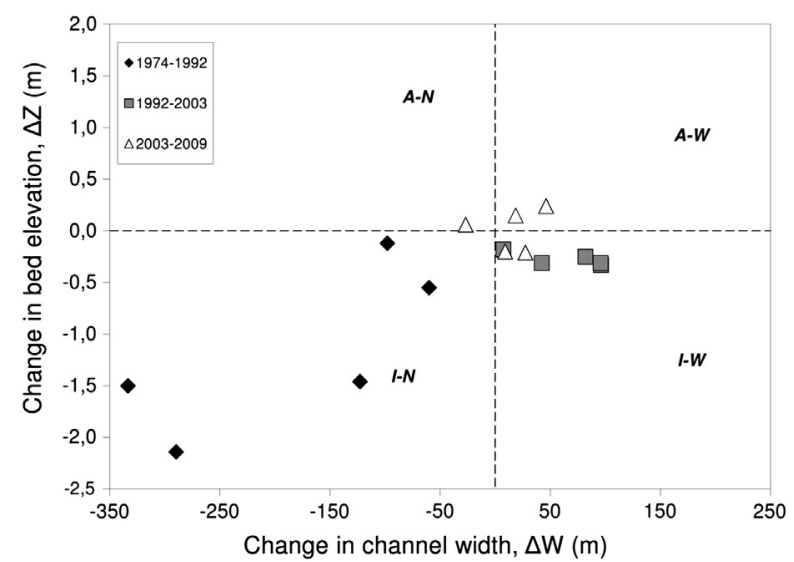

Fig. 5. Channel width vs. bed-level adjustments associated to the three periods of analysis. A: Bed aggradation; I: bed incision; $\mathrm{N}$ : channel narrowing; W: channel widening.

2006), it has also been recognized that different or extended sequences of channel evolution can be observed, depending on various factors. For example, Elliott et al. (1999) proposed a seven-stage evolution model to describe contemporary arroyos that formed in the late nineteenth and early twentieth centuries in many regions of the southwestern USA. Thorne (1999) proposed that an additional stage may be added to account for late-stage evolution from straight to meandering for some of the channels from which the original CEMs were developed. Hawley et al. (2012) have presented a novel five-stage CEM of semiarid stream response to altered hydrologic and sediment regimes associated with urbanization, which includes an evolutionary sequence of braided channel morphology. Finally, Cluer and Thorne (2013) have recently proposed a novel stream evolution model (SEM), including a precursor stage of possible multithread morphology prior to disturbance and introducing an evolutionary cycle framework within which streams may evolve through the common sequence, recover to a previous stage, lack some stages, or repeat part of the evolutionary cycle. This condition proximate to a morphological threshold is similar to the 'alternative stable state' concept developed for ecological systems (e.g., Beisner et al., 2003; Folke et al., 2004).

Various studies on channel evolution of Italian rivers included some consideration on the suitability of CEMs for such systems. Rinaldi and Simon (1998) observed that channel adjustments in the Arno River system (Tuscany, central Italy) differ from similar unstable fluvial systems altered by human disturbances because channel widening following degradation and subsequent aggradation in downstream reaches has been limited because of an extensive presence of bank protection. Surian and Rinaldi (2003) developed a classification scheme grouping the observed channel changes into a series of main categories of adjust- 528 ment. Similarly, Rinaldi (2003) proposed a regional classification scheme 529 of channel adjustments that occurred in Tuscan fluvial systems and 530 discussed some significant differences from CEMs, including (i) lack of 531 an aggradational phase and of a spatial distribution of dominant process- 532 es and trends; and (ii) channel narrowing rather than widening. These 533 variations were attributed to a series of possible factors and differences, 534 such as (i) geological bed controls; (ii) channel morphologies, bed and 535 bank materials; and (iii) diverse human disturbances. Subsequent stud- 536 ies (Surian and Rinaldi, 2004; Rinaldi et al., 2008, 2009; Surian et al., 537 2009) have reported an additional stage for a series of rivers in northern 538 Italy consisting of widening and slight aggradation that occurred after 539 1990. This new stage could be related to a delayed response to the cessa- 540 tion of the intensive sediment exploitation of the previous period 541 (Rinaldi et al., 2009) and/or to a change of channel geometry and an in- 542 crease of unit stream power (Ziliani and Surian, 2012).

\subsection{A conceptual framework of channel evolution of the Trebbia River}

544

Based on the trajectories of morphological adjustments, in this sec- 545 tion we propose a more detailed sequence of stages of channel evolu- 546 tion over the last 60 years, i.e., covering the period of phases 2 and 3547 described in previous studies on the Trebbia and other Italian rivers 548 (Pellegrini et al., 2008; Rinaldi et al., 2009; Surian et al., 2009).

549

Before this study, very few cases included sufficient bed-elevation 550 data to allow investigation in more detail on relations between width 551 and bed-level adjustments and consequently the application of a CEM. 552 In the following part we summarize the results obtained for the Trebbia 553 River and discuss them in the context of an evolutionary framework in 554 relation to possible causes and factors.

From the results of the study of the Trebbia River changes, there is 556 evidence of a partially cyclic evolutionary trend, with a sequence of 557 four stages of evolution and shifts in dominant adjustment processes 558 but without a return to the initial stage (Fig. 7). Compared to other 559 CEMs where the evolutionary sequence starts from a stable, 'undis- 560 turbed' condition, such an initial stage is more problematic to identify 561 in the case of most Italian rivers. Previous works generally report a 562 first phase of incision and narrowing generally started at the end of 563 the nineteenth century and continued up to the 1950s, which has 564 been interpreted as a result of afforestation, bank protection, and even- 565 tually a reduction of sediment delivery related to the end of the Little Ice 566 Age. Therefore, the beginning of the 1950s (stage I) cannot be consid- 567 ered as the initial, 'undisturbed' condition, but rather as the start of a 568 new evolutionary cycle overlapping a previous degradational phase. 569 The main disturbances causing the start of this new degradational 570 phase (stage II) can be considered a combination of the drastic increase 571 of sediment removal after World War II and the construction of dams 572
A

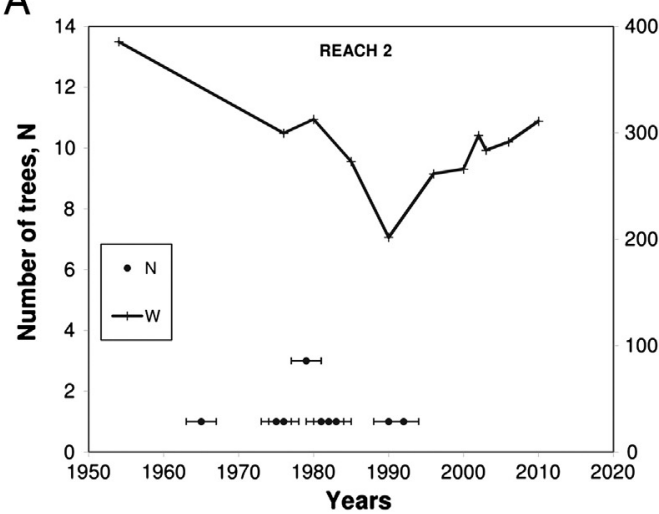

B

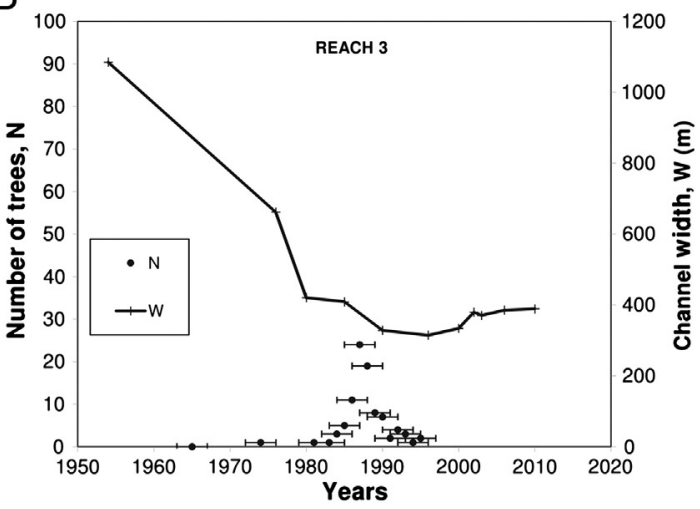

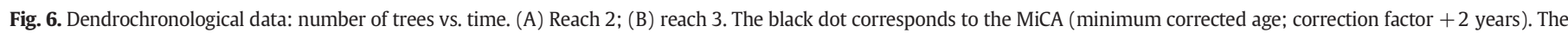
horizontal bar indicates the time interval between the real measured age of trees (on the right) and the MaCA (maximum corrected age; correction factor +4 years). 

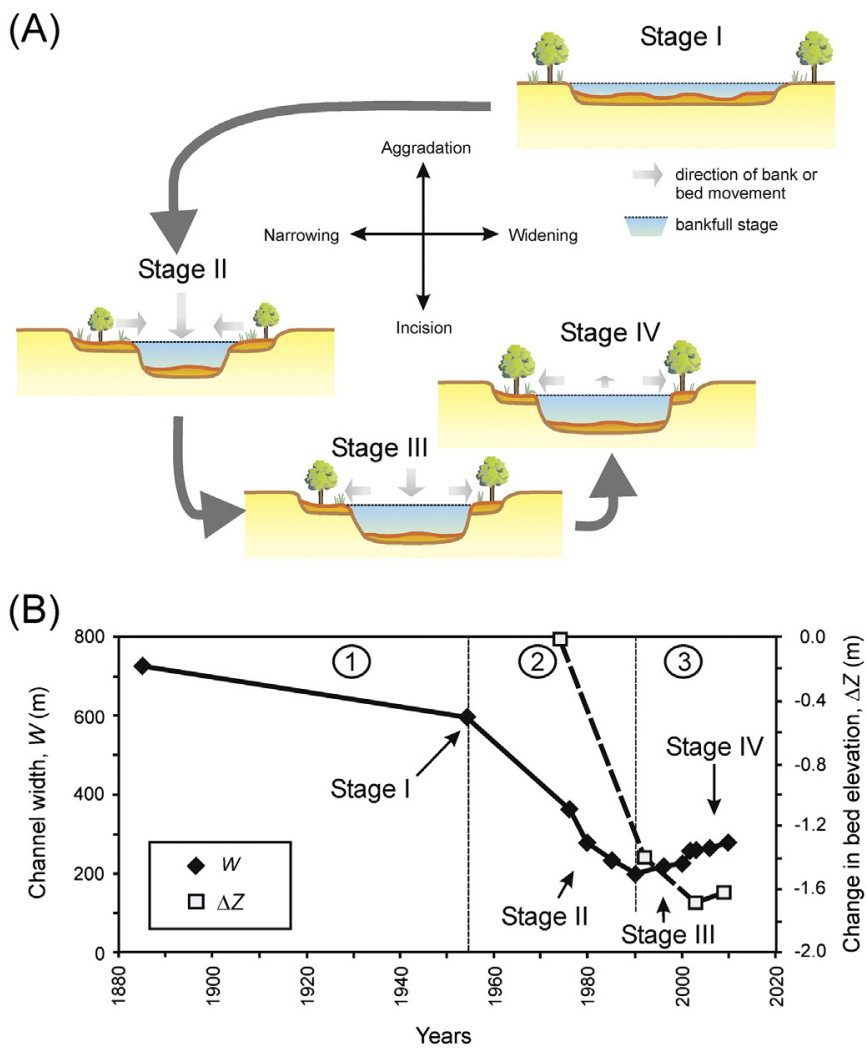

Fig. 7. Conceptual framework of channel evolution for the lower Trebbia River. (A) Four stages of channel evolution. (B) Stages of channel evolution associated with the trends of width and bed-level adjustment at segment-scale showed in Fig. 3.

upstream. Data on the Trebbia River clearly show that bed incision and channel narrowing act simultaneously, at least during the period of available bed level data (1974-1992) (Fig. 5).

Existing information on the Trebbia River, as well as on other Italian rivers, suggests that it is not possible to determine whether incision and narrowing started contemporarily or whether one of the two adjustments favored the other. For example, in the case of French rivers, narrowing usually occurred slightly before the incision as it was also associated with afforestation of the river corridors (about 1930s to the late 1960s) in areas that were actively used for grazing; whereas incision reached a peak in the 1970s in relation to intense mining activity (Liébault and Piégay, 2001, 2002). In small tributaries of these rivers, channel narrowing occurred in association with formation of terraces from a decrease of sediment supply with a clear downstream progressing pattern (Liébault et al., 2005).

Channel narrowing represents an apparent difference compared to CEMs applied in the USA, as they predict a phase of channel widening. A series of reasons can explain this difference: (i) channel widening of CEMs refers to the overall cross section, while narrowing of Italian rivers is referred to the channel width intended as low water channels and unvegetated bars, delimitated by the margins of the new terraces generated by incision (Rinaldi, 2003); (ii) bank instability related to bed incision, which is indicated as the cause of widening, is a dominant factor in single-thread, mostly cohesive channels of CEMs. This process is less important in wide, coarse-grained, transitional, or braided channels, where reduction of bedload (induced by sediment removal) and fast colonization and encroachment of abandoned surfaces by vegetation are more relevant factors.

Dendrochronological data support the evidence that vegetation has a primary role during the late narrowing stage. Island and riparian forests along new floodplain surfaces were established mostly during the period 1985-1990, i.e., during the phase of maximum narrowing, and have played an important role in starting the recovering phase. This time interval during which the greater number of trees along reaches 606 2 and 3 germinated may be considered corresponding to the geomor- 607 phological and pioneer stages of the BLC of $P$. nigra L., as indicated by 608 Corenblit et al. (2014), when the survival of trees is strictly linked to 609 their location in respect to the active channels. An important human 610 factor during this phase of maximum narrowing could also be the pro- 611 mulgation of a national law (1985), which prohibits the cutting of veg- 612 etation along riparian corridors, and therefore promoting vegetation 613 encroachment that otherwise, in previous decades, would be partially 614 removed by local owners of agricultural lands and inhabitants for do- 615 mestic use.

The results from the Trebbia River clearly show that after incision 617 and narrowing there was a following phase (1992-2003) (stage III) dur- 618 ing which a slight incision was associated to the start of widening 619 (Fig. 5). The association between incision and widening has been rarely 620 observed in other Italian case studies. For example, Rinaldi et al. (2009) 621 observed along the Magra River that there is good correspondence be- 622 tween the reversal of temporal trends in channel width and bed eleva- 623 tion such that an increase in channel width is usually associated with a 624 phase of aggradation and vice versa. The reversal of the channel width 625 trend from narrowing to widening has been so far attributed to a lagged 626 response to the end of the intensive sediment removal (end of the 627 1980s). Although this could represent an indirect cause, the actual 628 mechanism triggering the start of widening has not been explained. $\quad 629$

Widening in some CEMs becomes a dominant process characterizing 630 the stage after incision because the banks exceed a critical height for 631 mass failure. In the case of the Trebbia, as previously noted, bank insta- 632 bility does not appear to represent a dominant process in controlling 633 channel width because of different bank material (mainly coarse- 634 grained) and the wider channel morphology. In this case, the reason 635 for the start of a widening phase is not completely known, but a possible 636 hypothesis is that relatively frequent flows - which would normally 637 spill over the floodplain - are constrained within the incised and nar- 638 row channel. Therefore, the noticeable change of channel geometry dur- 639 ing the phase of narrowing has produced an increase of unit stream 640 power in the reach (Ziliani and Surian, 2012).

The encroachment by arboreal vegetation may have further promot- 642 ed concentration of flow in the new channel bed, by increasing rough- 643 ness along the new surfaces, and therefore increasing stream power 644 per unit channel width. Therefore, high unit stream power may be re- 645 sponsible for an increasing erosive action and therefore starts to pro- 646 mote lateral erosion by fluvial sediment entrainment. Once lateral 647 erosion starts, the introduction of wood in the channel may be an addi- 648 tional mechanism, besides sediment supply, to explain a further ten- 649 dency to lateral shifting.

This stage may also correspond to the biogeomorphological stage of 651 the BLC (2-15 year-old trees) (Corenblit et al., 2014), which is charac- 652 terized by the strong growth increase in stem and roots systems. This 653 is immediately followed by the ecological stage (15-30 years-old 654 trees) when mature trees are located on stabilized floodplains and 655 islands and their future depends on the persistence of the geomorphic 656 surface in response to a disturbance regime, as for example channel mi- 657 gration (Corenblit et al., 2014). Some of the riparian community may be 658 destroyed (as visually observed in the local situation along the Trebbia 659 River during the multitemporal surveys) or survive, transforming into 660 a hardwood terrestrial formation.

Available data on the late stage of evolution (2003-2009) (stage IV) 662 along the Trebbia River are still limited, but they support the idea that in 663 some reaches a possible reversal of bed-level trend has started to occur, 664 i.e., from incision to slight aggradation or stability, although for some 665 other reaches incision is still occurring (Fig. 5). The reversal of bed- 666 level trend is clearly attributable to the start of widening during the pre- 667 vious stage, and the consequent increase in sediment delivery. 668

Ziliani and Surian (2012) attributed a major role to bank erosion in 669 the recovery of the Tagliamento River, while catchment-scale processes 670 were not considered as playing a significant role. Furthermore, as for the 671 
previous stage, widening also promotes introduction of wood derived from the new forested riparian areas therefore favoring further lateral erosion and bed-level recovery.

Unlike CEMs, no clear evidence of a temporal pattern of adjustments is observed. This can be related to the different human disturbances affecting the Trebbia River and other Italian rivers. Sediment removal may be the dominant type of disturbance along the study reaches during the twentieth century, which trigger or accelerate bed incision. Sediment mining has been extensively and simultaneously carried out at many points along the main alluvial channels and tributaries of the fluvial systems. Incision at the points of extraction is a direct result of sediment mining in situ, while upstream and downstream migrating effects (Kondolf, 1994; Rinaldi et al., 2005b) produced bed degradation along the reaches between the pits. The adjustments mostly occurred longitudinally in synchronism along the rivers affected by mining.

A summary of the stages of channel evolution observed along the Trebbia River is shown in Fig. 7. Periodic oscillations and partial reversals of temporal trends can be related to the occurrence of high magnitude floods or to periods within which a relatively high frequency of significant flow events occurred. Notably cyclic evolution does not imply that the river will recover its initial morphology, but rather a cyclic sequence of combinations of width and bed-level adjustments occurs. In fact, existing data on the Trebbia and other Italian rivers show that the amount of widening and aggradation of the current stages of evolution is still a minor amount of the incision and narrowing that has occurred from the 1950s to the beginning of the 1990s. In the case of the Trebbia River, channel widening ranges from about $10 \%$ to $60 \%$ of the amount of previous narrowing. Not enough data on bed-level changes exist, but the available information suggests that aggradation is still a relatively small part of the previous incision. However a complete recovery of channel width could temporarily occur during intense flood events. For example, this has been observed along the Orco River where a very large flood (the largest recorded in the twentieth century) occurred in October 2000 (Pellegrini et al., 2008; Surian et al., 2009) and more recently along the Magra River during a flood (25/10/2011) with a return period of 100-200 years (Nardi and Rinaldi, submitted for publication). In these cases, channel width can be comparable to the 1950s; however, a partial colonization of vegetation on the new channel bed could again decrease the channel width over the years following the flood.

\section{Conclusions}

This paper presents a study on channel evolution of a 22-km alluvial segment of the Trebbia River (northern Italy), a very interesting fluvial system not only from a scientific point of view but also for cultural and educational opportunities (Bollati et al., 2012). The focus is on reach-scale dynamics over the last 60 years. Multitemporal analysis of aerial photos allowed reconstruction of detailed trajectories of change in channel width. Topographic cross sections allowed definition of the main bed-level changes with a lower temporal frequency. These analyses then allowed the investigation of reach-scale patterns of channel width and bed-level adjustments and identification of a sequence of stages of channel evolution. Tree-ring data analysis provided additional information on channel evolution and on the life cycle of riparian community during the 1980 s to 2010 s time interval.

Some main conclusions can be summarized as follows:

- A sequence of stages of channel adjustment can be identified. The first part of an evolutionary cycle represents the main response to disturbances (i.e., sediment mining and upstream dams are the most relevant), dominated by narrowing and incision. A second part represents the partial recovery phase, dominated by widening.

- We observed channel incision combined with widening, which was not yet well documented for other Italian rivers. We also observed slight aggradation or bed stability combined with widening, but higher uncertainty exists on this combination of processes, although they have been observed in other Italian case studies with similar 735 characteristics.

736

- Observed changes can be set in an evolutionary framework of existing 737 CEMs, as similar shifts of dominant processes are observed, but with 738 some difference that can be related to various factors. A conceptual 739 model of channel evolution specific for the Trebbia River better repre- 740 sents these specific features and could be applied to a wider range of 741 Italian rivers with similar characteristics in terms of valley setting, 742 channel morphology, and types and chronology of human distur- 743 bances. Additional data are needed to confirm some aspects of and 744 to verify extension of this sequence to other Italian rivers, as well as 745 to understand the extent of recovery phases in the future. 746

- Finally, these findings can be relevant in terms of river management. A 747 channel evolution model based on the knowledge of past trajectories 748 of morphological change can provide important information on possi- 749 ble future trends and therefore on morphological potential and possi- 750 ble endpoint targets for river management or restoration. Historical 751 range of variability is a useful tool. However, this historical range 752 should be used in combination with channel evolution models in 753 order to set the current evolution in the most recent evolutionary 754 framework. Historical conditions cannot be used often as a reference 755 of possible future changes because previous catchment/floodplain 756 conditions have completely changed and these changes may be irre- 757 versible. Therefore, identification of the most recent evolutionary 758 cycle can provide a much more realistic range of morphological condi- 759 tions that can be potentially reached in the future, assuming that no 760 other controlling variables change.

\section{Acknowledgements}

The research was performed in the framework of the PRIN 2007 pro- 763 ject Present evolutionary trends and possible future dynamics of alluvial 764 channels in northern and central Italy (National Coordinator Dr. Surian 765 Nicola, Local Coordinator Prof. Pellegrini Luisa). The authors thank Dr. A. 766 Bazzi for helping in dendrochronological analysis and for support in the 767 field survey and Dr. Davide Zizioli for the support during topographic 768 surveys of cross sections and related data elaboration.

769

Appendix A. Supplementary data

770

Supplementary data associated with this article can be found in the 771 online version, at doi:10.1016/j.geomorph.2014.06.007. These data in- 772 clude Google map of the most import areas described in this article. $\quad 773$

\section{Appendix A. Supplementary data}

774

Supplementary data to this article can be found online at http://dx. 775 doi.org/10.1016/j.geomorph.2014.06.007.

\section{References}

Astrade, L., Bégin, Y., 1997. Tree-ring response of Populus tremula L. and Quercus robur L. to 778 recent spring floods of the Saône River, France. Ecoscience 4, 232-239.

Beisner, B.E., Haydon, D. Cuddington, K.L., 2003. Alternative stable states Front. Ecol. Environ. 1, 376-382. Dufour, S., Piégay, H., 2013. Regional variability of aquatic patterns in braided 782 reaches (example of the French Rhône basin). Hydrobiologia 712, 25-41. http://dx. 783 doi.org/10.1007/s10750-012-1279-6.

Bledsoe, B.P., Stein, E.D., Hawley, R.J., Booth, D., 2012. Framework and tool for rapid as- 785 sessment of stream susceptibility to hydromodification. J. Am. Water Res. Assoc. 48786 (4), 788-808.

Bollati, I., Pelfini, M., Pellegrini, L., 2012. A geomorphosites selection method for educa- 788 tional purposes: a case study in Trebbia Valley (Emilia Romagna, Italy). Geogr. Fis. 789 Dinamica Ouaternaria 35 (1), 23-35.

Brierley, G.J., Fryirs, K.A., Boulton, A., Cullum, C., 2008. Working with change: the impor- 791 tance of evolutionary perspectives in framing the trajectory of river adjustment. In: 792 Brierley, G., Fryirs, K.A. (Eds.), River Futures: An Integrative Scientific Approach to 793 River Repair. Society for Ecological Restoration International, Island Press, Washing- 794 ton, DC, USA, pp. 65-84.

Cluer, B., Thorne, C.R., 2013. A stream evolution model integrating habitat and ecosystem 796 benefits. River Res. Appl. 30 (2), 135-154. http://dx.doi.org/10.1002/rra.2631. 
Comiti, F., Da Canal, M., Surian, N., Mao, L., Picco, L., Lenzi, M.A., 2011. Channel adjustments and vegetation cover dynamics in a large gravel bed river over the last 200 years. Geomorphology 125, 147-159. http://dx.doi.org/10.1016/j.geomorph.2010.09.011.

Cook, E.R., 1985. A time series approach to tree-ring standardization. (Ph.D. Dissertation) Univ. of Arizona, Tucson, USA

Corenblit, D., Tabacchi, E., Steiger, J., Gurnell, A.M., 2007. Reciprocal interactions and adjustments between fluvial landforms and vegetation dynamics in river corridors: a review of complementary approaches. Earth Sci. Rev. 84 (1), 56-86.

Corenblit, D., Steiger, J., González, E., Gurnell, A.M., Charrier, G., Darrozes, J., dousseau, J., Julien, F., Lambs, L., Larrue, S., Roussel, E., Vautier, F., Voldoire, O., 2014. The biogeomorphological life cycle of poplars during the fluvial biogeomorphological succession: a special focus on Populus nigra L. Earth Surf. Process. Landf. 39 (4), 546-563. http://dx.doi.org/10.1002/esp.3515.

Downs, P.W., Dusterhoff, S.R., Sears, W.A., 2013. Reach-scale channel sensitivity to multiple human activities and natural events: lower Santa Clara River, California, USA Geomorphology 189, 121-134. http://dx.doi.org/10.1016/j.geomorph.2013.01.023.

Downward, S.R., Gurnell, A.M., Brookes, A., 1994. A methodology for quantifying river Erosion and Sediment Transport, International Association Hydrological Sciences Publication 224, Canberra, Australia, pp. 449-456.

Duci, G., 2011. Variazioni morfologiche recenti ed attuali di alvei fluviali dell'Appennino Settentrionale. (PhD Thesis) Scuola di Dottorato in Scienze e Tecnologie, Univ. of Pavia, Italy,

Dufour, S., Piégay, H., 2009. From the myth of a lost paradise to targeted river restoration: forget natural references and focus on human benefits. River Res. Appl. 25 (5), $568-581$.

Elliott, J.G., Gellis, A.C., Aby, S.B., 1999. Evolution of arroyos: incised channels of the southwestern United States. In: Darby, S.E., Simon, A. (Eds.), Incised River Channels: Processes, Forms, Engineering and Management. Wiley, Chichester, UK, pp. 153-185.

Everitt, B.L., 1968. Use of the cottonwood in an investigation of the recent history of flood plain. Am. J. Sci. 266, 417-439. http://dx.doi.org/10.2475/ajs.266.6.417.

Folke, C., Carpenter, S.R., Walker, B., Scheffer, M., Elmqvist, M.T., Gunderson, L., Holling, C S., 2004. Regime shifts, resilience, and biodiversity in ecosystem management. Annu. Rev. Ecol. Evol. Syst. 35, 557-581.

Garavaglia, V., Pelfini, M., Motta, E., 2010. Glacier stream activity in the proglacial area of an Italian debris covered glacier: an application of dendroglaciology. Geogr. Fis. Dinamica Quaternaria 33 (1), 15-24.

Gottesfeld, A.S., Johnson-Gottesfeld, L.M., 1990. Floodplain dynamics of a wandering river dendrochronology of the Morice River, British Columbia, Canada. Geomorphology 3 , 159-179.

Gurnell, A.M., 1997. Channel change of the river Dee meanders, 1946-1992, from the analysis of air photographs. Regul. Rivers Res. Manag. 13, 13-26.

Gurnell, A.M., Surian, N., Zanoni, L., 2009. Multi-thread river channels: a perspective on changing European Alpine river systems. Aquat. Sci. 71, 253-265. http://dx.doi.org/ 10.1007/s00027-009-9186-2.

Gurnell, A.M., González del Tánago, M., Rinaldi, M., Grabowski, R., Belletti, B., Henshaw, A., O'Hare, M., Buijse, A.D., 2014. Development and application of a multiscale processbased framework for the hydromorphological assessment of European rivers. Proceedings IAEG XII Congress, Torino, September 2014. Springer (in press).

Gutsell, S.L., Johnson, E.A., 2002. Accurately ageing trees and examining their heightgrowth rates: implications for interpreting forest dynamics. J. Ecol. 90, 153-166.

Hawley, R.J., Bledsoe, B.P., Stein, E.D., Haines, B.E., 2012. Channel evolution model of semiarid stream response to urban induced hydromodification. J. Am. Water Resour. Assoc. 48 (4), 722-744. http://dx.doi.org/10.1111/j.1752-1688.2012.00645.x

Holmes, R.L., Adams, R.K., Fritts, H.C., 1986. Tree-ring chronologies of North America: California, Eastern Oregon and Northern Great Basin with procedures used in the chronology development work including user manual for computer program COFECHA and ARSTAN. Chronology Series VIUniversity of Arizona, Laboratory of tree-ring research, Tucson, Usa,.

Hughes, M.L., MacDowel, P.F., Marcus, W.A., 2006. Accuracy assessment of georectified aerial photographs: implications for measuring lateral channel movement in a GIS. Geomorphology 74, 1-16. http://dx.doi.org/10.1016/j.geomorph.2005.07.001.

Hupp, C.R., 1992. Riparian vegetation recovery patterns following stream channelization: a geomorphic perspective. Ecology 73 (4), 1209-1226.

Hupp, C.R., Bornette, G., 2003. Vegetation, fluvial processes and landforms in temperate areas. In: Piégay, H., Kondolf, M. (Eds.), Tools in Geomorphology. John Wiley and Sons, Chichester, England, pp. 269-288.

Hupp, C.R., Osterkamp, W.R., 1996. Riparian vegetation and fluvial geomorphic processes. Geomorphology 14, 277-295.

Hupp, C.R., Rinaldi, M., 2007. Riparian vegetation patterns in relation to fluvial landforms and channel evolution along selected rivers of Tuscany (Central Italy). Ann. Assoc Am. Geogr. 97 (1), 12-30.

Hupp, C.R., Simon, A., 1991. Bank accretion and the development of vegetated deposition surfaces along modified alluvial channels. Geomorphology 4 (2), 111-124

Jones, C.G., Lawton, J.H., Shachak, M., 1994. Organisms as ecosystem engineers. Oikos 69, 373-386.

Koch, J., 2009. Improving age estimates for late Holocene glacial landforms using dendrochronology - some examples from Garibaldi Provincial Park, British Columbia. Quat. Geochronol. 4, 130-139.

Kondolf, G.M., 1994. Geomorphic and environmental effects of instream gravel mining. Landsc. Urban Plan. 28, 225-243.

Liébault, F., Piégay, H., 2001. Assessment of channel changes due to long term bedload supply decrease, Roubion River, France. Geomorphology 36 (3-4), 167-186.

Liébault, F., Piégay, H., 2002. Causes of 20th century channel narrowing in mountain and piedmont rivers of southeastern France. Earth Surf. Process. Landf. 27, 425-444.
Liébault, F., Gomez, B., Page, M., Marden, M., Peacock, D., Richard, D., Trotter, C.M., 2005. 883 Land-use change, sediment production and channel response in upland regions. 884 River Res. Appl. 1 (7), 739-756. http://dx.doi.org/10.1002/rra.880.

Liébault, F., Lallias-Tacon, S., Cassel, M., Talaska, N., 2013. Long profile responses of alpine 886 braided rivers in SE France. River Res. Appl. 29 (10), 1253-1266. http://dx.doi.org/10. 887 1002/rra.2615.

Nardi, L., Rinaldi, M., 2014. Spatio-temporal patterns of channel changes in response to a Q3 major flood event: the case of the Magra River (central-northern Italy). Earth Surf. 890 Process. Landf. (submitted for publication).

Pelfini, M., Leonelli, G., Santilli, M., 2006. Climatic and environmental influences on Moun- 892 tain Pine (Pinus Montana Miller) growth in the Central Italian Alps. Arct. Antarct. Alp. 893 Res. 38 (4), 614623.

Pellegrini, L., Maraga, F., Turitto, O., Audisio, C., Duci, G., 2008. Evoluzione morfologica di 895 alvei fluviali mobili nel settore occidentale del Bacino Padano. II Quaternario 21896 (1B), 251-266.

Piégay, H., Alber, A., Slater, L., Bourdin, L., 2009. Census and typology of the braided rivers 898 in the French Alps. Aquat. Sci. 71 (3), 371-388.

Pierson, T.C., 2007. Dating young geomorphic surfaces using age of colonizing Douglas fir 900 in southwestern Washington and northwestern Oregon, USA. Earth Surf. Process. 901 Landf. 32, 811-831.

Regent Instruments Inc., 2001. Windendro 2001, User Manual. Regent Instruments, Que- 903 bec, Canada,

Rinaldi, M., 2003. Recent channel adjustments in alluvial rivers of Tuscany, Central Italy. 905 Earth Surf. Process. Landf. 28 (6), 587-608.

Rinaldi, M., 2008. Schede di rilevamento geomorfologico di alvei fluviali. II Quaternario 21907 (1B), 353-366.

Rinaldi, M., Simon, A., 1998. Bed-level adjustments in the Arno River, Central Italy. Geo- 909 morphology 22 (1), 57-71.

Rinaldi, M., Simoncini, C., Sogni, D., 2005a. Variazioni morfologiche recenti di due alvei 911 ghiaiosi appenninici: il F.Trebbia ed il F.Vara. Geografia Fisica Dinamica Quaternaria 912 Suppl VII, pp. 313-319.

Rinaldi, M., Wyżga, B., Surian, N., 2005b. Sediment mining in alluvial channels: physical 914 effects and management perspectives. River Res. Appl. 21 (7), 805-828.

Rinaldi, M., Teruggi, L.B., Simoncini, C., Nardi, L., 2008. Dinamica recente ed attuale di alvei 916 fluviali: alcuni casi di studio dell'Appennino Settentrionale. II Quaternario 21 (1B), 917 291-302.

Rinaldi, M., Simoncini, C., Piégay, H., 2009. Scientific design strategy for promoting sus- 919 tainable sediment management : the case of the Magra river (Central-Northern 920 Italy). River Res. Appl. 25, 607-625. http://dx.doi.org/10.1002/rra.1243.

Rinaldi, M., Surian, N., Comiti, F., Bussettini, M., 2013. A method for the assessment and 922 analysis of the hydromorphological condition of Italian streams: the Morphological 923 Quality Index (MQI). Geomorphology 180-181, 96-108.

Rinn, F. 1996. TSAP. Time Series Analysis and Presentation, Version 3.0 Reference Manual 925 Rinntech, Heidelberg.

Schumm, S.A., Harvey, M.D., Watson, C.C., 1984. Incised Channels: Morphology, Dynamics, 927 and Control. Water Resources Publication, Littleton, Colorado, (200 pp.).

Scott, M.L. Auble, G.T., Friedman, J.M., 1997. Flood dependency of cottonwood establish- 929 ment along the Missouri River, Montana, USA. Ecol. Appl. 7 (2), 677-690.

Sigafoos, R.S., 1964. Botanical evidence of floods and flood-plain deposits. US Geological 931 Professional Paper 485-a, pp. 1-26.

Simon, A., 1989. A model of channel response in disturbed alluvial channels. Earth Surf. 933 Process. Landf. 14, 11-26.

Simon, A., Hupp, C.R., 1986. Channel evolution in modified Tennessee channels. Proc. 935 Fourth Federal Interagency Sedimentation Conference, 24-27 March 1986, Las 936 Vegas, Nevada, 2, pp. 5-51-5-60.

Simon, A., Rinaldi, M., 2000. Channel instability in the loess area of the Midwestern United 938 States. J. Am. Water Resour. Assoc. 36 (1), 133-150.

Simon, A., Rinaldi, M., 2006. Disturbance, stream incision, and channel evolution: the roles 940 of excess transport capacity and boundary materials in controlling channel response. 941 Geomorphology 79, 361-383.

Simon, A., Thorne, C.R., 1996. Channel adjustment of an unstable coarse-grained stream: 943 opposing trends of boundary and critical shear stress and the applicability of 944 extremal hypotheses. Earth Surf. Process. Landf. 21, 155-180.

Surian, N., Cisotto, A., 2007. Channel adjustments, bedload transport and sediment 946 sources in a gravel-bed river, Brenta River, Italy. Earth Surf. Process. Landf. 32, 947 1641-1656. http://dx.doi.org/10.1002/esp.1591.

Surian, N., Rinaldi, M., 2003. Morphological response to river engineering and manage- 949 ment in alluvial channels in Italy. Geomorphology 50, 307-326. http://dx.doi.org/ 950 10.1016/S0169-555X(02)00219-2.

Surian, N., Rinaldi, M., 2004. Channel adjustments in response to human alteration of sed- 952 iment fluxes: examples from Italian rivers. In: Golosov, V., Belyaev, V., Walling, D.E. 953 (Eds.), Sediment Transfer through the Fluvial System, Proc. Symposium iMoscow, Au- 954 gust 2004. IAHS Publ., 288, pp. 276-282.

Surian, N., Rinaldi, M., Pellegrini, L., Audisio, C., Maraga, F., Teruggi, L.B., Turitto, O., Ziliani, L. 956 2009. Channel adjustments in Italian rivers: evolutionary trends, causes and man- 957 agement implications. In: James, L.A., Rathburn, S.L., Whittecar, G.R. (Eds.), Manage- 958 ment and Restoration of Fluvial Systems with Broad Historical Changes and Human 959 Impacts. Special Paper, 451. Geological Society of America Boulder, U.S.A., pp. 83-95. 960

Thorne, C.R., 1999. Bank processes and channel evolution in the incised rivers of North- 961 Central Mississippi. In: Darby, S.E., Simon, A. (Eds.), Incised River Channels: Processes, 962 Forms, Engineering and Management. Wiley, Chichester, UK, pp. 97-122.

Winterbottom, S.J. 2000. Medium and short-term channel planform changes on the Riv- 964 ers Tay and Tummel, Scotland. Geomorphology 34, 195-208.

Ziliani, L., Surian, N., 2012. Evolutionary trajectory of channel morphology and controlling 966 factors in a large gravel-bed river. Geomorphology 173-174, 104-117. 